RESEARCH ARTICLE

Nurdan Arican ${ }^{1}$

D Murat Tunc ${ }^{1}$

${ }^{1}$ Duzce Eye Diseases Service, Duzce, Ataturk State Hospital, Duzce, Turkey

${ }^{2}$ Ankara Tunc Eye Diseases Clinic, Ankara, Turkey

Corresponding Author: Nurdan Arican

Duzce Eye Diseases Service, Duzce Ataturk State Hospital, 81000,

Duzce, Turkey

mail: nurdanbsb@hotmail.com

Phone: +90 38052913 00/2340

Received: 18.08 .2020

Acceptance: 22.09 .2020

DOI: 10.18521/ktd.782163

Konuralp Medical Journal e-ISSN1309-3878

konuralptipdergi@duzce.edu.tr konuralptipdergisi@gmail.com www.konuralptipdergi.duzce.edu.tr

\section{Evaluation of Demographic Factors Affecting Peripapillary Nerve Fiber Thickness by Optical Coherence Tomography in Diabetic Patients \\ ABSTRACT}

Objective: To investigate the demographic factors affecting the peripapillary nerve fiber thickness(PNFL) measured with optical coherence tomography(OCT) in diabetic patients.

Methods: A total of 207 eyes of 104 diabetic patients ( 92 eyes of 46 males, 115 eyes of 58 female) who were followed-up between 2009-2013 were included. PNFL was measured with OCT in the superior, inferior, temporal and nasal quadrants and compared with demographic factors.

Results: PNFL was found to be thinner in superior and inferior at the age of 60 years and above compared to under 60 years $(\mathrm{p}=0.004, \mathrm{p}=0.001)$. There is a significant relationship between gender and the average PNFL only in inferior quadrants $(\mathrm{p}=0.006)$. There is no relationship between hypertension and the mean PNFL in 4 quadrants $(\mathrm{p}>0.05)$. Superior PNFL was decreased in eyes with glaucoma compared to those without glaucoma $(\mathrm{p}=0.019)$. The mean PNFL in superior, inferior and nasal patients with diabetes duration of more than 15 years decreased compared to those with 15 years or less $(\mathrm{p}=0.048, \mathrm{p}=0.020, \mathrm{p}=0.020)$. Temporal PNFL was decreased in eyes without retinopathy compared to eyes with proliferative diabetic retinopathy $(\mathrm{PDR})$ and non- $\mathrm{PDR}(\mathrm{p}=0.025)$. Temporal PNFL was increased both in patients with diabetic macular edema(DME) and the patients treated with panretinal photocoagulation $(\mathrm{p}=0.001, \mathrm{p}=0.001)$. No correlation was found between the mean PNFL in four quadrants with focal laser treatment $(\mathrm{p}>0.05)$.

Conclusions: Age, gender, duration of diabetes, glaucoma, DME, PDR, non-PDR have an effect on PNFL, but HT and focal laser have not. In addition, the duration of diabetes and the presence of diabetic retinopathy(DR) should be taken into account when evaluating the progression of PNFL defects in patients with both glaucoma and diabetes.

Keywords: Diabetes Mellitus, Peripapillary Nerve Fiber Thickness, Optical Coherence Tomography, Demographic Factors

\section{Diyabetik Hastalarda Peripapiller Sinir Lifi Kalınlığını Etkileyen Demografik Faktörlerin Optik Koherens Tomografi ile Değerlendirilmesi}

ÖZET

Amaç: Diyabetik hastalarda optik koherens tomografi (OKT) ile ölçülen peripapiller sinir lifi kalınlığını (PLSK) etkileyen demografik faktörleri araştırmaktır.

Gereç ve Yöntem: Bu çalıșmaya 2009-2013 yılları arasında izlenen 104 diyabetik hastanın (46 erkek hastanın 92 gözü, 58 kadın hastanın 115 gözü) toplam 207 gözü dahil edildi. PLSK, OCT ile üst, alt, temporal ve nazal kadranlarda ölçüldü ve demografik faktörlerle karșılaștırıldı.

Bulgular: 60 yaş ve üzerinde ortalama PSLK, 60 yaş altına göre üst ve alt kadranda daha ince olduğu görüldü $(\mathrm{p}=0,004, \mathrm{p}=0,001)$. Cinsiyet ile ortalama PSLK arasında sadece alt kadranlarda anlamlı bir ilişki vardır $(\mathrm{p}=0,006)$. Dört kadranda da hipertansiyon(HT) ile ortalama PSLK arasında ilişki yoktur( $\mathrm{p}>0.05)$. Glokomlu gözlerde, glokomu olmayanlara göre üst kadranda ortalama PLSK azalmaktadır $(\mathrm{p}=0.019) .15$ yıldan fazla diyabet süresi olan hastalarda üst, alt ve nazal kadranlarda ortalama PLSK, 15 yıl veya daha az olanlara göre azaldığı görüldü( $\mathrm{p}=0,048, \mathrm{p}=0,020, \mathrm{p}=0,020)$. Retinopatisi olmayan gözlerde ortalama temporal PLSK, proliferatif diyabetik retinopatili (PDR) ve non-PDR olan gözlerle karșılaștırıldığında azalmıştı $(\mathrm{p}=0,025)$. Temporal PLSK hem diyabetik maküla ödemi (DMÖ) olan hem de panretinal fotokoagülasyon uygulanan hastalarda artmıştı $(\mathrm{p}=0,001, \mathrm{p}=0,001)$. Fokal lazer tedavisi uygulanan hastalarla dört kadrandaki ortalama PLSK arasinda korelasyon bulunmadi $(\mathrm{p}>0.05)$.

Sonuç: Yaş, cinsiyet, diyabet süresi, glokom varlığı, DMÖ, PDR-nonPDR gibi faktörlerin PSLK üzerine etkisinin olduğu fakat HT, fokal lazer gibi faktörlerin PSLK üzerine etkisi yoktur. Ayrıca hem glokomu hem de diyabeti bulunan olgularda, retina sinir lifi defektlerinin progresyonunu değerlendirirken diyabet süresi ve diyabetik retinopati mevcudiyetinin dikkate alınması gerekir.

Anahtar Kelimeler: Diyabetes Mellitus, Peripapiller Sinir Lifi Kalınlı̆̆ı, Optik Koherens Tomografi, Demografik Faktörler 


\section{INTRODUCTION}

Diabetes mellitus, which is common all over the world and characterized by abnormal insulin secretion and increased blood glucose levels, is a chronic disease affecting the circulatory and nervous system, kidney and eye, and causing microvascular events $(1,2)$. Clinically, the most important effect of microangiopathy associated with diabetes is on the retina and choroid, however, the pathogenesis of diabetes, especially its effects on the ocular circulation, has not been fully elucidated (3). Circulatory disorders seen in diabetes occur with the increase in the resistance of the retinal vascular bed to blood flow. In most diabetic patients, in addition to characteristic findings in the blood vessels, changes also occur in the blood structure. As a result of these disorders, changes occur in the flow rate of the blood (4).Ocular blood flow velocities in patients with diabetic retinopathy have been reported to be increased by some researchers (5) and decreased by others $(6,7)$.

RNFL is located in the inner retina just below the internal limiting membrane (1-3). The fibers in this layer consisting of 1.0-1.3 million axons of retinal ganglion cells combine in the optic disc and form the optic nerve (1).Today, damages in RNFL can be detected in the early period with OCT and other RNFL imaging methods (2).OCT is a technique in which high resolution tomographic sectional images of the retina and optic nerve are obtained in a non-contact, non-invasive manner using light at a wavelength of $\sim 800 \mathrm{~nm}$ (5).Tomographic cross-sectional images of the optic disc and retina are obtained by making use of the back reflection of infrared light from tissue layers similar to the B-mode ultrasound principle $(4,5)$. In this study, we evaluated the measurements of PNFL with OCT, which is used extensively in our clinic, in order to investigate the factors that affect PNFL in diabetic patients. The relationship between demographic factors such as age, gender, systemic hypertension (HT), duration of diabetes, diabetic retinopathy level, diabetic macular edema, presence of glaucoma, panretinal photocoagulation and laser treatment and PNFL were examined in patients with DM in this present study.

\section{MATERIAL AND METHODS}

A total of 207 eyes of 104 diabetic patients, including 92 eyes of 46 male patients and 115 eyes of 58 female patients, who were followed up and treated in Düzce University Medical Faculty Ophthalmology Outpatient Clinic between July 2009 and January 2013 were included in this retrospective study. One eye of 1 patient was excluded due to phthisis bulbi. Patients without glaucoma $(n=59)$ were selected from diabetic cases with intraocular pressure of $21 \mathrm{mmHg}$ and below and with normal disc appearance. Eyes with glaucoma $(n=45)$ were selected from patients with diabetes who were diagnosed with glaucoma during examination at our clinic, whose intraocular pressure (IOP) was measured high, and who were previously followed and treated with a diagnosis of glaucoma. Goldman applanation tonometer was used to measure IOP. All glaucoma cases included in the study were selected from those who came for control at least three times. Patients with very large and very small optic disc were excluded in the study. Patients with microaneurysms, dot or lineshaped intraretinal hemorrhages, hard exudates, diffuse hemorrhage, venous pilling, and intraretinal microaneurysm were divided into nonproliferative DR; neovascularization in the disc, retinal neovascularization, preretinal or intra-vitreous hemorrhage, fibrovascular proliferation, iris and iridocorneal neovascularization patients were divided into proliferative DR.

$$
\text { Information such as demographic }
$$

characteristics of the patients, presence of hypertension, presence of glaucoma, duration of diabetes, diabetic retinopathy level, diabetic macular edema, and laser photocoagulation therapy were obtained from the patients' hospital records. Following the routine ophthalmologic examination in all cases, PSLK measurements were made by two ophthalmologists (NA, MT) with the OCT device. Nerve fiber thicknesses of the nasal, temporal, superior and inferior quadrants for all eyes were determined as micron $(\mu)$. A high resolution OCT device (TOPCON SD-Optical Coherence Tomography) was used for measurement. The factors whose effects on PNFL were investigated in patients with DM were age, gender, HT, diabetes duration, DR's stage, retinopathy, DME, panretinal photocoagulation and focal laser treatment. The effect of age factor on PNFL was examined by forming two groups: over 60 and under 60, and the duration of diabetes over 15 years and under 15 years. This study was approved by the Düzce University Medical Faculty non-invasive health research ethics committee (2012/301) and all patients were informed about the study, informed consent form and ethical approval were obtained.

Statistical Analysis: Descriptive statistics (mean, standard deviation, minimum, maximum, percentage values) of all data in the study were calculated. Kalmagarov-Smirnov test was used to examine the variables in the continuous nature with the assumption of normality. In this respect, MannWhitney U and Kruskal-Wallis tests were used for comparisons between groups according to the number of groups. While evaluating the findings obtained in the study, an appropriate computer program (SPSS 19) was used for statistical analysis. A p $<0.05$ was considered statistically significant.

\section{RESULT}

A total of 104 (60 [n:119 eyes] female, 44 [n:88 eyes] male) patients who diagnosed diabetes mellitus were included in this present study. In 
addition, 50 ( $n=99$ eyes) were under the age of 60 and $54(\mathrm{n}=108$ eyes) were 60 and over of the 104 cases.

The PSLK was thinner in the superior and inferior quadrants in patients aged 60 and over than those under 60 years of age. There is a statistically significant correlation in the superior and inferior quadrants when age and the average PSLK in 4 quadrants are evaluated $(\mathrm{p}=0.004, \mathrm{p}=0.001)$. Average PSLK in women was found to be thicker than men. When gender and average PSLK in 4 quadrants are evaluated. There is a statistically significant relationship in the inferior quadrant $(\mathrm{p}=$ 0.006) (Table 1).

Table 1. Average PFNL change by age and gender

\begin{tabular}{lllllll}
\hline \multirow{2}{*}{ PFNL } & Age & \multicolumn{3}{c}{ Gender } & P \\
\cline { 2 - 9 } & $\begin{array}{l}<60(\mathrm{n}=99) \\
\text { mean } \pm \text { SD }\end{array}$ & $\begin{array}{l}\geq 60(\mathrm{n}=108) \\
\text { mean } \pm \mathrm{SD}\end{array}$ & $\begin{array}{l}\text { female }(\mathrm{n}=119) \\
\text { mean } \pm \mathrm{SD}\end{array}$ & $\begin{array}{l}\text { male }(\mathrm{n}=88) \\
\text { mean } \pm \mathrm{SD}\end{array}$ & $* \mathrm{p}$ & $* * \mathrm{p}$ \\
\hline superior & $106.93 \pm 22.3$ & $94.87 \pm 33.4$ & $103.04 \pm 27.9$ & $97.38 \pm 30.7$ & 0.004 & 0.131 \\
\hline inferior & $112.84 \pm 23.7$ & $99.31 \pm 29.0$ & $109.77 \pm 25.0$ & $100.38 \pm 29.6$ & 0.001 & 0.006 \\
\hline temporal & $66.36 \pm 17.7$ & $63.01 \pm 22.6$ & $67.01 \pm 18.2$ & $61.37 \pm 22.8$ & 0.119 & 0.277 \\
\hline nasal & $75.31 \pm 23.2$ & $70.75 \pm 29.6$ & $75.99 \pm 25.5$ & $68.79 \pm 28.1$ & 0.132 & 0.087 \\
\hline
\end{tabular}

PFNL: peripapillary nerve fiber thickness, SD: Standard deviation, n: number of participants

While 71 of 104 diabetic patients $(n=141$ eyes) had HT, 33 patients ( $n=66$ eyes) did not have HT. There is no significant relationship between the presence of systemic HT and the average PSLK in 4 quadrants ( $p>0.05)$. In a study of 207 eyes of 104 diabetic patients, 114 eyes with glaucoma and 93 without glaucoma were examined. In eyes with glaucoma, the superior mean PSLK was significantly decreased compared to eyes without glaucoma $(\mathrm{p}=0.019)$ (Table 2).

Table 2. Average PFNL change according to the presence of systemic hypertension and glaucoma

\begin{tabular}{lcccccc}
\hline PFNL & $\begin{array}{c}\mathrm{HT}(+)(\mathrm{n}=141) \\
\text { mean } \pm \text { SD }\end{array}$ & $\begin{array}{c}\mathrm{HT}(-)(\mathrm{n}=66) \\
\text { mean } \pm \mathrm{SD}\end{array}$ & $\begin{array}{c}\text { Glaucoma }(+) \\
(\mathrm{n}=114) \text { mean } \pm \text { SD }\end{array}$ & $\begin{array}{c}\text { Glaucoma }(-) \\
(\mathrm{n}=93) \text { mean } \pm \mathrm{SD}\end{array}$ & $\mathrm{P}^{*}$ & $\mathrm{P}^{* *}$ \\
\hline superior & $100.72 \pm 29.1$ & $100.47 \pm 29.5$ & $109.50 \pm 26.8$ & $103.00 \pm 29.2$ & 0.916 & 0.019 \\
\hline inferior & $106.91 \pm 28.2$ & $103.36 \pm 25.5$ & $112.50 \pm 28.2$ & $108.00 \pm 27.4$ & 0.081 & 0.133 \\
\hline temporal & $65.25 \pm 20.8$ & $63.24 \pm 19.7$ & $66.50 \pm 21.9$ & $65.00 \pm 20.4$ & 0.445 & 0.058 \\
\hline nasal & $72.09 \pm 24.4$ & $74.73 \pm 31.4$ & $74.00 \pm 26.1$ & $72.00 \pm 26.8$ & 0.877 & 0.453 \\
\hline
\end{tabular}

PFNL: peripapillary nerve fiber thickness, HT: hypertension SD: Standard deviation, n: number of participants

The mean duration of diabetes in 104 diabetic patients was found to be $12.4 \pm 7.6(0.08$ 30) years. When the average PSLK change in 4 quadrants in 148 eyes with a diabetes duration of 15 years or less and 59 eyes with a diabetes duration of 15 years was evaluated. The mean PSLK in the superior, inferior, and nasal quadrants in 59 eyes over 15 years was significantly reduced compared to those with 15 years or less $(p=0.048, p=0.020$, $p=0.020) .62$ of 207 eyes have DME and 145 eyes have no DME. When the mean PSLK change in 4 quadrants was evaluated according to the presence of DME, the PSLK in the temporal quadrant increased significantly in DME eyes $(p=0.001)$ (Table 3).

Table 3. Change in PNFL according to DM duration and DME

\begin{tabular}{lcccccc}
\hline \multirow{2}{*}{ PFNL } & $\begin{array}{c}\leq 15 \text { year }(\mathrm{n}=148) \\
\text { mean } \pm \text { SD }\end{array}$ & $\begin{array}{c}>15 \text { year }(\mathrm{n}=59) \\
\text { mean } \pm \text { SD }\end{array}$ & $\begin{array}{c}\text { DME }(+)(\mathrm{n}=62) \\
\text { mean } \pm \text { SD }\end{array}$ & $\begin{array}{c}\text { DME(-) }(\mathrm{n}=145) \\
\text { mean } \pm \text { SD }\end{array}$ & P* & P** \\
\hline superior & $109.00 \pm 27.5$ & $104.00 \pm 29.2$ & $99.88 \pm 28.9$ & $100.96 \pm 29.3$ & 0.048 & 0.512 \\
\hline inferior & $112.00 \pm 28.4$ & $105.00 \pm 27.4$ & $111.11 \pm 25.4$ & $103.50 \pm 27.9$ & 0.020 & 0.442 \\
\hline temporal & $65.00 \pm 22.6$ & $65.00 \pm 20.4$ & $73.46 \pm 18.7$ & $60.82 \pm 20.0$ & 0.758 & 0.000 \\
\hline nasal & $75.00 \pm 24.3$ & $69.00 \pm 26.8$ & $74.76 \pm 26.4$ & $72.15 \pm 27.0$ & 0.020 & 0.884 \\
\hline
\end{tabular}

PFNL: peripapillary nerve fiber thickness, SD: Standard deviation, DME: diabetic macular edema, DM: diabetes mellitus, n: number of participants

While 27 of 207 eyes had PDR and 88 had NPDR, 92 eyes had no retinopathy. When the mean PSLK change in 4 quadrants was evaluated according to the presence of DR, it was found that the PSLK in the temporal quadrant was significantly decreased in eyes without retinopathy compared to eyes with PDR and NPDR $(\mathrm{p}=0.025)$. There is no significant relationship between the PSLK in the temporal quadrant in eyes with PDR and non-PDR $(\mathrm{p}=0.349)$ (Table 4). Focal laser was applied to 14 of 207 eyes, panretinal photocoagulation was applied to 72 eyes, but no laser treatment was applied to 121 eyes. When the average PSLK change in 4 quadrants is evaluated in patients who underwent focal laser or panretinal photocoagulation, in eyes with focal laser applied, the mean PSLK in the superior quadrant is $99.50 \pm$ 35.3 , inferior $110.57 \pm 15.3$, temporal $64.86 \pm 23.4$ 
and nasal $78.29 \pm 33.8 \mu \mathrm{m}$. In eyes with panretinal photocoagulation, the mean PSLK in the superior quadrant is $97.78 \pm 33.4$, inferior $105.78 \pm 32.0$, temporal $70.50 \pm 23.1$ and nasal $73.92 \pm 32.8 \mu \mathrm{m}$. The PSLC significantly increased in the temporal quadrant in eyes with panretinal photocoagulation $(\mathrm{p}=0.001)$. There is no significant relationship between focal laser eyes and PSLK in four quadrants $(\mathrm{p}>0.05)$.

Table 4. PNFL change according to the presence of DR

\begin{tabular}{lcccc}
\hline PFNL & $\begin{array}{c}\text { PDR }(+)(\mathrm{n}=27) \\
\text { mean } \pm \text { SD }\end{array}$ & $\begin{array}{c}\text { Non-PDR }(+)(\mathrm{n}=88) \\
\text { mean } \pm \text { SD }\end{array}$ & $\begin{array}{c}\text { retinopathy(-) }(\mathrm{n}=92) \\
\text { mean } \pm \text { SD }\end{array}$ & P \\
\hline superior & $96.07 \pm 33.8$ & $99.35 \pm 29.5$ & $103.21 \pm 27.4$ & 0.188 \\
\hline inferior & $95.93 \pm 41.2$ & $108.11 \pm 24.3$ & $106.45 \pm 24.8$ & 0.176 \\
\hline temporal & $62.44 \pm 26.7$ & $69.43 \pm 19.7$ & $60.64 \pm 18.2$ & 0.025 \\
\hline nasal & $70.48 \pm 40.1$ & $72.92 \pm 25.9$ & $73.66 \pm 22.8$ & 0.579 \\
\hline $\begin{array}{l}\text { PFNL: peripapillary nerve fiber thickness, SD: Standard deviation,DR:diabetic retinopathy,PDR: Proliferative diabetic retinopathy, n: } \\
\text { number of participants }\end{array}$
\end{tabular}

\section{DISCUSSION}

Clinically, the most important effect of diabetic microangiopathy is on the retina and choroid. In addition to characteristic findings in the blood vessels, changes occur in the flow rate of the blood in most diabetic patients (4). It has been stated in previous studies that thinning, defects or both may occur in RNFL in patients with DM (9, 10). Chiara et al. showed that defects are common in RNFL in patients with early diabetic retinopathy, and that advanced age, stages of diabetic retinopathy and systemic hypertension are risk factors for these defects (10). Conceiçao et al. showed that retinal thickness increased in type 2 diabetics with mild nonproliferative retinopathy in their 3-year follow-up (11). Similarly, Lopes de Faria et al thought that there was nerve fiber loss only in the upper quadrant, which was probably due to low perfusion in 12 patients with type $1 \mathrm{DM}$ (12).

The age factor affecting PNFL differs in various studies $(10,13)$. In a study conducted by Lee et al in a patient group with a mean age of $42.90 \pm 16.15$ (302 eyes, 155 patients, age range 20-79), RNFL thickness decreases by $2.1 \mu \mathrm{m}$ per decade ( $\mathrm{p}<0.001$ ) (13). In our study, PNFL was found to be significantly thinner in the superior and inferior quadrants in patients aged 60 and over $(\mathrm{p}=$ $0.004, p=0.001$ ). In a study conducted by Nakatani et al., it was observed that gender had no effect on PNFL (14). However, in our study, PNFL was found to be thicker in the inferior quadrant in women $(\mathrm{p}=0.006)$.

Before the onset of small vessel damage, increased blood pressure in the early period in HT patients may result in increased blood flow or greater hydrostatic resistance developed against the occlusion of small vessels. With this result, it can protect ganglion cells and their axons from damage (14). Later, when small vessel damage occurs and resistance to flow increases, a positive relationship can be detected between optic nerve damage and HT.

Tielsch et al. results obtained in his study support this hypothesis (15). The protective effect of HT is observed among those younger than 60 years old, and the adverse effect is observed among those aged 70 years and over. As a result, Tielsch et al. demonstrated that ocular perfusion pressure is associated with a higher risk of primary open angle glaucoma. At the same time, they stated that other parameters of HT may cause a moderate risk increase (15). Cheung et al. showed that parameters such as age, IOP, axial length had an effect on retinal nerve fiber thickness measured by spectral domain-OCT, but parameters such as systemic blood pressure had little effect in their study on 542 eyes without glaucoma (16). In our study, no statistically significant difference was found between PNFL in all 4 quadrants and systemic HT ( $p>0.05$ ). In order to understand more confidently to what extent PNFL can be affected by hypertension, larger series and studies with untreated HT patients are needed.

Glaucoma is a multifactorial disease characterized by visual impairment, optic neuropathy and loss of retinal ganglion cells (8). Retinal ganglion cells; the retinal nerve fiber layer consisting of ganglion cell axons, the ganglion cell layer (GCL), and the inner-plexiform layer consisting of ganglion cell dendrites. These three layers are called ganglion cell complex (GCC). This layer becomes thinner due to ganglion cell death in glaucoma (16).

In the longitudinal OCT study of Schuman et al., the mean RNFL thickness was $95.9 \pm 10.09$ $\mu \mathrm{m}$ in the normal group $(\mathrm{n}=107), 80.3 \pm 18.4 \mu \mathrm{m}$ in the early glaucoma group $(\mathrm{n}=64)$, and $50.7 \pm$ $13.6 \mu \mathrm{m}$ in the advanced glaucoma group ( $\mathrm{n}=$ 18)(17). Towsend et al. obtained significant results in their study on measuring optic nerve head and retinal nerve fiber analysis with OCT in glaucoma patients (18). In a study by Leung et al. found that optic nerve head and RNFL measurement with OCT are useful in diagnosing glaucoma in the early period (19). One issue that needs to be addressed in the study is that the effect of disc surface area on nerve fiber thickness measurement is neglected. While RNFL was examined with OCT, in our study, as in all other studies, a standard diameter circle was scanned. The disadvantage of using a 
standard diameter is that the measurement is made closer to the disc edge in cases with large optic disc surface area, whereas in cases with small disc surface area, this measurement is made further. It is known that the closer the thickness of the retinal nerve fiber layer is measured to the edge of the disc, the thicker it will be. In addition, it has been reported that the number of nerve fibers may be higher in eyes with large optic disc (19).

Chihara et al. showed in their study with scanning laser ophthalmoscope (SLO) that significant RNFL defects were observed in diabetic patients, similar to defects in glaucoma, but the $\mathrm{c} / \mathrm{d}$ ratio did not increase (20). In this study, it is reported that diabetes-related RNFL loss in DM patients can be differentiated from normal tension glaucoma by not increasing the $\mathrm{c} / \mathrm{d}$ ratio. It was also shown in the study by Klein et al. that they followed diabetic patients for four years and that the $\mathrm{c} / \mathrm{d}$ ratio did not increase (21).

In the study of Takahashi and Chihara on 38 eyes with diabetes and glaucoma, they showed that RNFL thickness was thinning in all four quadrants ( $p$ <0.01) (22). In our study, it was observed that eyes with glaucoma in 207 eyes with diabetes were significantly thinner $(\mathrm{p}=0.019)$. Therefore, complete evaluation of the structural damage of the RNFL, GCC and optic nerve is extremely important in the early diagnosis and follow-up of glaucomatous optic neuropathy. It is natural that the thickness of the nerve fiber layer in eyes with glaucoma is thinner than in normal eyes(22). The reason for this is the damage to the optic disc / nerve fiber layer in the glaucoma group included in the study, and the differences in nerve fiber layer thickness in eyes with glaucoma and normal eyes have been emphasized in many studies $(22,23)$.

It is accepted by all ophthalmologists that the duration of diabetes is one of the most important risk factors for the development and severity of DR (24-26). It can be stated that the increase in diabetes duration results in the proliferation of ischemic areas in the retina in parallel with the increasing microangiopathy and thus causes thinning in RNFL. Sugimoto et al. performed with OCT in Type 2 DM patients without DR that they reported a statistically significant decrease in the superior quadrant compared to the control group (27). In addition, diabetes duration of Type 2 DM patients was 94.80 \pm 87.60 months in this study. Lopes et al. in their study using scanning laser polarimetry (NFA-GDx) in Type $1 \mathrm{DM}$ patients without diabetic retinopathy, they also found a statistically significant decrease in the superior quadrant compared to the control group, And also, type 1 DM patients without retinopathy and those with a diabetes duration of at least 10 years were included in this study (12). Another study, Chihara et al. showed that RNFL defects were significantly higher in Type 1 and Type 2 DM patients without retinopathy compared to the control group. And also, among Type 1 and Type 2 DM patients without retinopathy, those with a diabetes duration of at least 10 years were included in the study(28). Ido et al. examined with NFA-1 in type 2 DM patients that they showed that RNFL thickness was inversely proportional to the duration of diabetes (29).

In our study, the mean PNFL in the superior, inferior and nasal quadrants was significantly decreased in patients with diabetes duration of more than 15 years $(\mathrm{p}=0.048, \mathrm{p}=0.020, \mathrm{p}=0.020)$. Accordingly, it can be said that the thinning of the temporal quadrant in DM develops more slowly than the other quadrants and the temporal quadrant is the most resistant to the effect of diabetes on RNFL. In many studies examining RNFL defects in DM patients with NPDR, the negative effect of diabetes on RNFL has been clearly shown $(19,20$, 29, 30, 31). Another study, Lopes et al. examined with NFA-GDx in Type 1 DM patients without diabetic retinopathy that they reported that there was a statistically significant decrease in the superior quadrant compared to the control group, and no thinning in the temporal quadrant (12). Sugimoto et al. stated that there was a statistically significant decrease in the superior quadrant compared to the control group, and there was no defect in the temporal quadrant (27). Another study, Chihara et al. showed that RNFL defects were significantly higher in Type 1 and Type 2 DM patients without retinopathy than in the control group (28). Barber et al. reported that neurodegeneration is an important component of DR by showing neural cell apoptosis in inner plexiform, inner nuclear layer and ganglion cells in diabetic guinea pigs and post mortem diabetic human eyes. In addition, DM triggers apoptosis in neuronal cells from the first month, even in the absence of DR in guinea pigs (31). In the light of this information, it can be said that the thinning of RNFL in DM occurs as a result of developing blood flow disorders and ischemia rather than apoptosis. Similar results was found in our study as published literature. And also, there is no publication in the literature showing the effect of DME on PNFL.

Although panretinal photocoagulation has been proven to be an effective treatment strategy for severe DR, the intensity of the laser used is decided by the physician (31,32). It has been reported that this high intensity laser beam can cause the destruction of the entire retinal layer, including ganglion cells. Ganglion cell damage results in loss of RNFL and a decrease in PSLK $(29,31,32)$. Kim et al. resulted that the panretinal photocoagulation used in DR treatment caused a decrease in PNFL in the treatment group, but this decrease was not found to be statistically significant compared to the control group on 282 eyes consisting of treatment $(\mathrm{n}=118$ eyes $)$ and control group ( $\mathrm{n}=164$ eyes) (32). In addition, they showed 
that while the blood HbAlc level was high, the decrease in PNFL was more pronounced.

There are no reports in the literature showing the effect of focal laser on PNFL. Another study performed with OCT showed a similar decrease in RNFL thickness after laser photocoagulation, however, they showed that hyperpigmented lesions affected the measurements by causing unreliable results $(16,33,34)$. Apple et al. drew our attention to another point that the effects of repeated treatments on RNFL should be taken into account when recurrent laser treatments are planned. If it is necessary to avoid RNFL damage, repetitive laser treatments should be applied within the first few hours after the first laser treatment (33). It is thought that retinal thickening due to edema observed in the early period after laser application protects the ganglion cells against the effects of laser treatment. Retinal damage increases as the retina becomes thinner during late treatments $(24,33)$.

\section{CONCLUSION}

In this present study, it was observed that factors such as age, gender, duration of diabetes, presence of glaucoma, panretinal photocoagulation, DME, PDR or non-PDR had an effect on PNFL, but factors such as systemic HT and focal laser did not have a significant effect on PNFL. In DR, damage occurs in retinal neurons together with microcirculation disorders. In order to understand the pathogenesis and treatment of DR, changes in retinal neurons and glial cells should be taken into consideration together with vascular pathologies. This study also suggests that the duration of diabetes and the presence of DR should be taken into account when assessing the progression of RNFL defects in patients with both glaucoma and diabetes. When thinning in RNFL is observed in cases with glaucoma and diabetes, it should be considered that this thinning may be related to glaucoma or the development of DR.

\section{REFERENCES}

1. Zeng Y, Cao D, Yu H, et al. Early retinal neurovascular impairment in patients with diabetes without clinically detectable retinopathy. Br J Ophthalmol. 2019;103(12):1747-52.

2. Lim HB, Shin YI, Lee MW, et al. Longitudinal Changes in the Peripapillary Retinal Nerve Fiber Layer Thickness of Patients With Type 2 Diabetes. JAMA Ophthalmol. 2019;137(10):1125-32.

3. Shin YI, Nam KY, Lee SE, et al. Peripapillary microvasculature in patients with diabetes mellitus: An optical coherence tomography angiography study. Sci Rep. 2019;9(1):15814

4. Mendivil A, Cuartero V, Mendivil MP. Ocular blood flow velocities in patients with proliferative diabetic retinopathy and healhy volunteers: a prospective study. Br J Ophthalmol 1995;79: 413-6.

5. Kohner EM, Hamilton AM, Saunders SJ, et al: The retinal blood flow in diabetes. Diabetologia 1975;1: 2233.

6. Erşanlı D, Ünal M, Çiftçi F, et al. Diabetik retinopatide oküler hemodinami. T Oft Gaz 1997;27: 342-46.

7. Mendivil A, Cuartero V. Ocular blood flow velocities in patients with proliferative diabetic retinopathy after scatter photocoagulation. Retina 1996;16: 222-27.

8. Lim HB, Lee MW, Park JH, et al. Changes in Ganglion Cell-Inner Plexiform Layer Thickness and Retinal Microvasculature in Hypertension: An Optical Coherence Tomography Angiography Study. Am J Ophthalmol. 2019;199:167-76.

9. Lopes JM, Russ H, Costa VP. Retinal nerve fiber layer loss in patients with type 1 diabetes mellitus without retinopathy. Br J Ophthalmol 2002; 86: 725-28.

10. Chiara H, Matsuoka T, Ogura Y,et al. Retinal nerve fiber layer defects as an early manifestation of diabetic retinopathy. Ophthalmology 1993; 100: 1147-51.

11. Conceiçao LL, Bernardes RC, Abreu RF, et al. One-year followup of blood-retinal barrier and retinal thickness alterations in patients with type 2 diabetes mellitus and mild nonproliferative retinopathy. Arch Ophthalmol 2001; 119: 1469-74.

12. Lopes de Faria JM, Russ H, Costa VP. Retinal nerve fibre layer loss in patients with type 1 diabetes mellitus without retinopathy Br J Ophthalmol 2002; 86: 725-28.

13. Jong Yeon Lee, Young Hoon Hwang, Sun Min Lee, et al. Age and Retinal Nerve Fiber Layer Thickness Measured by Spectral Domain Optical Coherence Tomography. Korean J Ophthalmol 2012;26(3):163-68

14. Yusuke Nakatani, MD, Tomomi Higashide, MD, PhD, Shinji Ohkubo, MD, et al. Evaluation of Macular Thickness and Peripapillary Retinal Nerve Fiber Layer Thickness for Detection of Early Glaucoma Using Spectral Domain Optical Coherence Tomography.J Glaucoma 2011;20:252-59.

15. Tielsch JM, Katz J, Sommer A, et al. Hypertension, Perfusion Pressure and open-angle glaucoma: A population base assessment. Arch. Ophthalmol 1995; 113:216-21

16. Carol Y. Cheung, David Chen, Tien Y. Wong, et al. Determinants of Quantitative Optic Nerve Measurements Using Spectral Domain Optical Coherence Tomography in a Population-Based Sample of Non-glaucomatous Subjects.Invest Ophthalmol Vis Sci. 2011 Dec 20;52(13):9629-35.

17. Schuman JS, Hee MR, Puliafito CA, et al. Quantification of nerve fiber layer thickness in normal and glaucomatous eyes using optical coherence tomography. Arch Ophthalmol. 1995;113:586- 96. 
18. Townsend KA, Wollstein G, Schuman JS. Imaging of the retinal nerve fiber layer for glaucoma. Br J Ophthalmol, 2009; Vol. 93 (2), pp. 139-43.

19. Leung CK, Chan WM, Hui YL, et al. Analysis of retinal nerve fiber layer and optic nerve head in glaucoma with different reference plane offsets, using optical coherence tomography. Invest Ophthalmol Vis Sci 2005; 46 (3), 891-9

20. Chihara E, Zhang S. Analysis of diabetic optic neuropathy with a topographic laser scanning system. Nippon Ganka Gakkas Zasshi 1998; 102: 431-35

21. Klein BEK, Moss SE, Magli YL, et al. Optic disc cupping: four year follow-up from the WESDR. Invest Ophthalmol Vis Sci 1989; 30: 310-15.

22. Hirokazu Takahashi and Etsuo Chihara. Impact of Diabetic Retinopathy on Quantitative Retinal Nerve Fiber Layer Measurement and Glaucoma Screening. Investigative Ophthalmology \& Visual Science, 2008;49: 2

23. Weinreb RN, Shakiba S, Zangwill L. Scanning laser polarimetry to measure the nerve fiber layer of normal and glaucomatous eyes. Am J Ophthalmol 1995; 119: 627-36.

24. Airaksinen PJ, Drance SM, Doulas GR, et al. Diffuse and localized nerve fiber loss in glaucoma. Am J Ophthalmol 1984; 98: 566-71.

25. Yoshida Y, Hagura R, Hana Y, et al. Risk factors for the development of diabetic retinopathy in Japanese type 2 diabetic patients. Diabetes Res ClinPract 2001; 51: 195-203

26. Dowse GK, Humphrey ARG, Colins VR, et al. Prevalance and risk factors for diabetic retinopathy in the multiethnic population of Mauritius. Am J Epidemiol 1998; 147: 448-57.

27. Sugimoto M, Wakitani Y, Takahashi C, et al. Detection of early diabetic change with optical coherence tomography in type 2 diabetes mellitus patients without retinopathy. Ophthalmologica 2005; 219: 379-85.

28. Chihara E, Matsuoka T, Ogura Y, et al. Retinal nerve fiber layer defect as an early manifestation of diabetic retinopathy. Ophthalmol 1993; 100: 1147-151.

29. Ido T, Inauzmi K, Chi Q, et al. Diabetic change in retinal nerve fiber layer thickness evaluated by scanning laser polarimetry. Invest Ophthalmol Vis Sci Annual(ARVO Suppl) 1995; 36: 482.

30. Konigsreuther KA, Jonas JB. Optic disc morphology in diabetes mellitus. Graefes Arch Clin Exp Ophthalmol 1995; 233: 200-04.

31. Barber AJ, Lieth E, Khin SA, et al. Neural apoptosis in the retina during experimental and human diabetes; early onset and effect of insulin. J Clin Invest 1998; 102: 783-91.

32. Ho Young Kim, MD, Ho Kyun Cho, MD, PhD. Peripapillary Retinal Nerve Fiber Layer Thickness Change After Panretinal Photocoagulation in Patients With Diabetic Retinopathy. Korean Journal of Ophthalmology 2009;23:23-6

33. Apple DJ, Wyhinny GJ, Goldberg MF et al: Experimental argon laser photocoagulation. III. Relative dangers of immediate vs delayed retreatment. Arch Ophthalmol. 1976; 94: 309-12.

34. Takahashi H, Goto $\mathrm{T}$, Shoji $\mathrm{T}$, et al. Diabetes-associated retinal nerve fiber damage evaluated with scanning laser polarimetry. Am J Ophthalmol 2006; 142: 88-94. 